\title{
THE PREVALENCE OF CHLAMYDIA TRACHOMATIS IN THE POPULATION LIVING IN ROMA SETTLEMENTS: A COMPARISON WITH THE MAJORITY POPULATION
}

\author{
Monika Halánová1 ${ }^{1}$ Pavol Jarčuška², Zuzana Kalinová1, Katarína Cáriková², Jaroslava Oravcová1, Peter \\ Jarčuška ${ }^{3}$, Daniel Pella ${ }^{3}$, Mária Mareková4, Andrea Madarasová Gecková5,6, Lýdia Čisláková1; HepaMeta Team* \\ ${ }^{1}$ Department of Public Health, Faculty of Medicine, P. J. Šafárik University in Košice, Košice, Slovakia \\ ${ }^{2}$ Department of Infectology and Travel Medicine, Faculty of Medicine, P. J. Šafárik University in Košice, Košice, Slovakia \\ ${ }^{31}$ st Department of Internal Medicine, Faculty of Medicine, P. J. Šafárik University in Košice, Košice, Slovakia \\ ${ }^{4}$ Department of Medical and Clinical Biochemistry and LABMED, Faculty of Medicine, P. J. Šafárik University in Košice, Košice, Slovakia \\ ${ }^{5}$ Health Psychology Unit, Department of Public Health, Faculty of Medicine, P. J. Šafárik University in Košice, Košice, Slovakia \\ ${ }^{6}$ Olomouc University Social Health Institute, Palacký University in Olomouc, Olomouc, Czech Republic
}

\section{SUMMARY}

Background: We aimed to study the occurrence of Chlamydia trachomatis infection in the population living in Roma settlements and to compare the obtained results with the prevalence in the majority population.

Methods: We examined 340 people for the presence of bacterium C. trachomatis, 208 of them were Roma (66 men, 142 women) and 132 were from the majority population (75 men, 57 women). Respondents were aged 18-55 years (mean age $=33.44, S T D=9.57)$. The occurence of C. trachomatis was detected by direct proof of the pathogen by polymerase chain reaction (PCR).

Results: Of 340 respondents included in the study, $22(6.5 \%)$ showed positivity for C. trachomatis infection, 15 of them were Roma (7.2\%) and 7 non-Roma (5.3\%). The highest positivity was detected in Roma women (8.5\%), while positivity in both non-Roma women and men was $5.3 \%$, and in Roma men $4.5 \%$. We did not confirm any significant contribution of age, gender or ethnicity to the occurrence of $\mathrm{C}$. trachomatis infection.

Conclusions: Despite the increased number of people with risk factors in the Roma community, no significant difference in the occurrence of C. trachomatis infection was found. Neither age nor gender contributes to the probability of $\mathrm{C}$. trachomatis infection. Nevertheless, there are other health consequences which might be more pronounced among the population living in Roma settlements due to barriers to the health care and their lower ability to benefit from health care services provided.

Key words: Chlamydia trachomatis, Roma population, non-Roma population, prevalence

Address for correspondence: Pavol Jarčuška, Department of Infectology and Travel Medicine, Faculty of Medicine, P. J. Šafárik University in Košice, Rastislavova 43, 04190 Košice, Slovakia. E-mail: jarcuska@upjs.sk

\section{INTRODUCTION}

Sexually transmitted infections are among the most common infections in adults. There are more than 30 bacterial, viral and parasitic sexually transmitted pathogens. If untreated, a number of them can lead to serious complications and sequelae (1).

Each year an estimated 340 million new cases of curable sexually transmitted infections occur worldwide, with the largest proportion in the region of South and South East Asia, followed by Sub-Saharan Africa, Latin America and the Caribbean (2). In Europe, the leading sexually transmitted infection is urogenital chlamydiosis, the reported incidence has increased dramatically over the last 20 years (3).

The risk factors for chlamydial infection include young age ( $<24$ years), new sexual partners and sexual risk behaviour

\footnotetext{
*HepaMeta Team members are listed in Appendix
}

(multiple sexual partners, non-use of condoms). In Slovakia, one of the groups of population which has a large number of people with these risk factors is the Roma community.

According to the Statistical Office of the Slovak Republic, 105,738 citizens from the total population of 5,397,036 in Slovakia are of Roma nationality, which represents only $2 \%$ of the population (4). However, the actual estimated number of Roma citizens in Slovakia ranges from around 320,000-500,000, which represents between 8.0 to $10 \%$ of the total population. Almost half of the Roma population in Slovakia is under the age of 18 years (5). Geographically, the highest number of Roma (approximately $60 \%$ ) lives in the eastern part of Slovakia. Aside from education, housing and employment, health is also one of the most critical areas of inequality of the Roma population. Around 150,000 Roma live in segregated places often located in rural areas without the necessary basic infrastructure and access to health care. Such settlements are concentrated into a small area with a large number of people whose health status is unsatisfactory. 
The majority of urogenital chlamydial infections in both women (80\%) and men (50\%) are asymptomatic; thus, Chlamydia trachomatis can be spread unknowingly and remains largely undiagnosed $(6,7)$. A laboratory examination is necessary to confirm diagnosis. But studies in Slovakia have confirmed that worse health in Roma is partially mediated by worse access to health services, apart from the large educational gap between Roma living in settlements and the majority population (8).

Therefore, the aim of this work was to study the occurrence of Chlamydia trachomatis infection in the population living in Roma settlements and to compare the obtained results with the prevalence in the majority population.

\section{MATERIALS AND METHODS}

\section{Study Population}

A total of 340 people were examined for the presence of the bacterium C. trachomatis during the cross-sectional populationbased HepaMeta study conducted in Eastern Slovakia in 2011 (primarily focused on detection of viral hepatitis B and C and metabolic syndrome) in the population living in separated and segregated Roma settlements. For comparison, we also examined people from the majority population. This study is described in detail elsewhere (9).

People from the Roma population were recruited directly in the settlements with the cooperation of local Roma community workers. Participation in the study was fully voluntary and anonymous.

Of 340 people examined, 208 were Roma (66 men, 142 women) and 132 were from the majority population (75 men, 57 women). Respondents were aged $18-55$ years (mean age $=33.44$, $\mathrm{STD}=9.57$ ).

The study was performed in accordance with the principles of the Declaration of Helsinki and approved by the Ethics Committee of the Faculty of Medicine at P. J. Šafárik University in Košice (No. 104/2011).

\section{Collection of Samples}

The first portion of the urine sample was used for analysis: 20-25 ml of urine was collected in a dry sterile container and stored immediately at $4{ }^{\circ} \mathrm{C}$ until processed. In the laboratory $1 \mathrm{ml}$ of urine from each sample was collected in a sterile $1.5 \mathrm{ml}$ microtube and centrifuged at 10,000 r/min for $5 \mathrm{~min}$. The supernatant was discarded, and the pellet resuspended in $0.2 \mathrm{ml}$ of transport medium, which was then mixed thoroughly by vortexing.

\section{Laboratory Methods}

The occurrence of $C$. trachomatis was detected by direct proof of the pathogen by polymerase chain reaction (PCR) using the commercial DNA-sorb-AM nucleic acid extraction kit and the AmpliSens ${ }^{\circledR}$ Chlamydia trachomatis-EPh PCR kit (the Federal Budget Institution of Science, Moscow, Russia).

Extraction and purification of DNA as well as PCR analysis were performed according to the manufacturer's instructions.

\section{Statistical Methods}

Basic descriptive statistics were used for the analysis of the obtained results. Relative risks (RR) and their 95 percent confidence intervals (95\% CI) were estimated for the occurrence of C. trachomatis. The contributions of age, gender and ethnicity to the prevalence of $C$. trachomatis infection were assessed using a logistic regression model.

\section{RESULTS}

A sample was considered to be positive for Chlamydia trachomatis DNA if the 330-bp band was present in the gel.

Of 340 respondents included in the study, 22 (6.5\%) showed positivity for $C$. trachomatis infection, 15 of whom were Roma (7.2\%) and 7 non-Roma (5.3\%). The highest positivity was detected in Roma women (8.5\%). Positivity in both non-Roma women and men was $5.3 \%$ vs. $4.5 \%$ in Roma men (Table 1 ).

Upon comparison of the relative risk of C. trachomatis infection occurrence in the group of Roma and the group of non-Roma, we found the risk of infection to be nearly 1.4-times higher in the Roma group than in the group of majority population. This risk was 1.6-times higher for Roma women compared with the group of women from the majority population. Upon comparison of the group of Roma men with the group of non-Roma men, the relative risk for both groups was approximately the same. No significant difference was therefore observed between positive cases in the Roma and non-Roma groups (Table 2).

Table 1. Prevalence of C. trachomatis infection

\begin{tabular}{|l|c|c|c|c|c|c|}
\hline \multirow{2}{*}{} & \multicolumn{2}{|c|}{ Men } & \multicolumn{2}{c|}{ Women } & \multicolumn{2}{c|}{$\sum$} \\
\cline { 2 - 7 } & $\mathbf{N}$ & $\mathrm{n}(\%)$ & $\mathbf{N}$ & $\mathrm{n}(\%)$ & $\mathbf{N}$ & $\mathrm{n}(\%)$ \\
\hline Roma & 66 & $3(4.6)$ & 142 & $12(8.5)$ & 208 & $15(7.2)$ \\
\hline Non-Roma & 75 & $4(5.3)$ & 57 & $3(5.3)$ & 132 & $7(5.3)$ \\
\hline
\end{tabular}

Table 2. Difference between positive cases of Roma and nonRoma by gender

\begin{tabular}{|l|c|c|c|}
\hline & $\begin{array}{c}\text { Roma } \\
\mathrm{n}(\%)\end{array}$ & $\begin{array}{c}\text { Non-Roma } \\
\mathrm{n}(\%)\end{array}$ & $\begin{array}{c}\text { Relative risk } \\
(95 \% \mathrm{Cl})\end{array}$ \\
\hline Men & $3(4.6)$ & $4(5.3)$ & $0.85(0.2-3.67)$ \\
\hline Women & $12(8.5)$ & $3(5.3)$ & $1.6(0.47-5.48)$ \\
\hline$\Sigma$ & $15(7.2)$ & $7(5.3)$ & $1.4(0.57-3.25)$ \\
\hline
\end{tabular}

Table 3. The contribution of age, gender and ethnicity to the probability of $\mathrm{C}$. trachomatis infection positivity

\begin{tabular}{|l|c|c|}
\hline & No. of positive cases (\%) & OR (95\% Cl) \\
\hline Age & & $0.99(0.95-1.04)$ \\
\hline Gender & \multicolumn{2}{|l|}{} \\
\hline Male & $7(5.0)$ & $1.49(0.58-3.87)$ \\
\hline Female & $15(7.5)$ & 1 \\
\hline Ethnicity & \\
\hline Non-Roma & $7(5.3)$ & $1.28(0.49-3.33)$ \\
\hline Roma & $15(7.2)$ &
\end{tabular}


We did not confirm any significant contribution of age, gender or ethnicity to the occurrence of C. trachomatis infection (Table 3).

\section{DISCUSSION}

The aim of the study was to explore the occurrence of the Chlamydia trachomatis infection in the population living in Roma settlements and compare it with the prevalence in the majority population. Despite the increased number of people with risk factors in the Roma community, no significant difference in the occurrence was found. Neither age nor gender contributes to the probability of the occurrence of $C$. trachomatis infection.

The Roma population is the largest and most disadvantaged ethnic minority group in Europe, and is believed to be vulnerable to sexually transmittable diseases due to early initiation of sexual life, higher prevalence of unprotected sexual behaviour (10-14) and barriers in access to health care system (8).

Urogenital chlamydial infection is the leading sexually transmitted disease in Europe and a reason of considerable acute morbidity and long-term reproductive health problems. In women, chlamydial infection can lead to reproductive morbidity. Infection of the lower genital tract occurs in the endocervix. Some women develop urethritis with symptoms of dysuria without frequency or urgency. Others may develop an ascending infection that causes acute salpingitis with or without endometritis, also known as pelvic inflammatory disease (PID), which long-term consequences are chronic pain, ectopic pregnancy and tubal factor infertility (15). In men, chlamydial infection is the most common cause of non-gonococcal urethritis and epididymitis, however, approximately $50 \%$ of men are asymptomatic $(6,7)$. Urethritis is secondary to $C$. trachomatis infection in approximately 15 to
$55 \%$ of men. Symptoms, if present, include a mild to moderate clear to white urethral discharge. Untreated chlamydial infection can spread to the epididymis. Men with an asymptomatic infection serve as carriers of the disease spreading the infection while only rarely suffer long-term health problems themselves.

Early treatment is the best prevention not only for secondary complications but also for other STD. Screening is of great value among risk groups, mainly promiscuous individuals, intravenous drug users, people with low education level, and those refusing to use contraception. The question is whether the same approach used for this "selective" screening can be used for the general population (16).

Screening for $C$. trachomatis has medical and economic impact and has been introduced in most of European countries at the regional and national level (17). However, comparing the prevalence of Chlamydia trachomatis infections across countries is complicated, because most countries do not have mandatory reporting of urogenital chlamydial infections and in countries which have adopted mandatory reporting legislation, quality of the reporting system is poor (18). Such a comparison is also complicated due to the different diagnostic methods and sample selection techniques applied (19).

In Slovakia, there is no specific law establishing a systematic screening for this infection, and the disease is not included in the category of notifiable diseases. Therefore, data on prevalence of urogenital chlamydial infections differ significantly depending mainly on the diagnostic method used.

Screening for C. trachomatis infection in the Slovak population is only opportunistic; there is no system for regular screening. The lowest prevalence of $C$. trachomatis infection was measured in the university population (only 1.9\%), while the highest was recorded in the subgroup of HIV-positive patients, sterile women and professional soldiers. Studies covering the general popula-

Table 4. Overview of the screening for C. trachomatis infection in Slovakia

\begin{tabular}{|c|c|c|c|c|c|c|}
\hline Author & City/place & Population & Gender & $\begin{array}{c}\text { Diagnostic } \\
\text { method }\end{array}$ & Measured material & $\begin{array}{l}\text { Prevalence of } \\
\text { C. trachomatis }\end{array}$ \\
\hline Kacena et al. (20) & Jarovnice & Roma & women & LCR & 1st void urine & $3.9 \%$ \\
\hline Jarčuška et al. (21) & Košice & general & men & PCR & urethral swab & $7.0 \%$ \\
\hline Šimko et al. (22) & Bratislava & general & women & PCR & cervical swab & $4.8 \%$ \\
\hline Balogová (23) & Košice & university students & women, men & PCR & 1st void urine & $1.9 \%$ \\
\hline Špiláková et al. (24) & Košice, B. Bystrica & general & women & PCR & vaginal swab & $4.2 \%$ \\
\hline Jarčuška et al. (25) & Košice & university students & women & PCR & vaginal swab & $2.2 \%$ \\
\hline Točková et al. (26) & Košice & general & women & PCR & cervical swab & $4.7 \%$ \\
\hline Balogová et al. (27) & Košice & Roma & women & PCR & 1st void urine & $4.4 \%$ \\
\hline Balogová et al. (27) & Košice & $\begin{array}{c}\text { patients with } \\
\text { chronic hepatitis }\end{array}$ & women & PCR & 1st void urine & $3.3 \%$ \\
\hline Balogová et al. (27) & Košice & sterile women & women & PCR & $\begin{array}{l}\text { 1st void urine, } \\
\text { cervical swab }\end{array}$ & $17.4 \%$ \\
\hline Vološinová et al. (28) & Banská Bystrica & $\begin{array}{c}\text { professional } \\
\text { soldiers }\end{array}$ & women, men & PCR & $\begin{array}{l}\text { 1st void urine, } \\
\text { cervical swab }\end{array}$ & $22.2 \%$ \\
\hline Vološinová et al. (28) & Banská Bystrica & general population & women, men & PCR & $\begin{array}{l}\text { 1st void urine, } \\
\text { cervical swab }\end{array}$ & $5.3 \%$ \\
\hline Vološinová et al. (28) & Banská Bystrica & HIV positive & women, men & PCR & $\begin{array}{l}\text { 1st void urine, } \\
\text { cervical swab }\end{array}$ & $10.5 \%$ \\
\hline
\end{tabular}


tion of Slovakia have reported prevalence between 4.2 to $7.0 \%$. An overview of Slovak screening studies is presented in Table 4.

The prevalence of $C$. trachomatis infection in our sample (majority population: 5.3\%, Roma settlements: 7.2\%) corresponds with the findings of these studies.

In the first Slovak study on the prevalence of $C$. trachomatis, prevalence among woman from the Roma population in Jarovnice (a Roma settlement neighbourhood Sabinov) was measured at only $3.9 \%$ using ligase chain reaction. In the same study the prevalence of $C$. trachomatis among university students was $8.2 \%$ (20). In another study conducted by Balogová et al. in 2009, the prevalence of $C$. trachomatis infection in the Roma population in Košice (a city with approx. 250,000 inhabitants) was 4.4\% (27). Similar findings on the Roma population were reported in our study (Roma male: $4.5 \%$, Roma female: $8.5 \%$ ).

Despite the fact that Roma living in settlements do not differ from the majority population in the prevalence of $C$. trachomatis infection, the impact on health, particularly in terms of infertility, might be different and unfavourable compared with the majority population due to pregnancy at the earlier age among Roma women. Nevertheless, there are also other health consequences which might be more pronounced among the population living in Roma settlements due to barriers to the health care system and their lower ability to benefit from the health care services provided.

\section{Acknowledgement}

This research was partially supported by the Research and Development Support Agency, Contract No. APVV-20-032-11; by the Agency of the Slovak Ministry of Education for the Structural Funds of EU, project CEMIO-ITMS: 26220120058 (50\%). This paper was also partially funded within the framework of the project "Social determinants of health in socially and physically disadvantaged and other groups of population" (CZ.1.07/2.3.00/20.0063) and by Roche Slovensko, s. r. o.

\section{Conflict of Interests}

None declared

\section{APPENDIX}

HepaMeta Team: Peter Jarčuška, Andrea Madarasová Gecková, Mária Mareková, Daniel Pella, Leonard Siegfried, Pavol Jarčuška, Lýdia Pastvová, Ján Fedačko, Jana Kollárová, Peter Kolarčik, Daniela Bobáková, Zuzana Veselská, Ingrid Babinská, Sylvia Dražilová, Jaroslav Rosenberger, Ivan Schréter, Pavol Kristian, Eduard Veselíny, Martin Janičko, Ladislav Virág, Anna Birková, Marta Kmet’ová, Monika Halánová, Darina Petrášová, Katarína Cáriková, Viera Lovayová, Lucia Merkovská, Lucia Jedličková, Ivana Valková

\section{REFERENCES}

1. World Health Organization. Prevalence and incidence of selected sexually transmitted infections, Chlamydia trachomatis, Neisseria gonorrhoeae, syphilis and Trichomonas vaginalis: methods and results used by WHO to generate 2005 estimates. Geneva: WHO; 2011.

2. World Health Organization. Global strategy for the prevention and control of sexually transmitted infections: 2006 - 2015: breaking the chain of transmission. Geneva: WHO; 2007.
3. Low N, et al.; European Centre for Disease Prevention and Control. Review of chlamydia control activities in EU countries. ECDC Technical Report. Stockholm: ECDC; 2008.

4. Juhaščíková I, Škápik P, Štukovská Z. The 2011 Census of Population and Housing - basic data. Population by nationality. Bratislava: The Statistical Office of the Slovak Republic; 2012. (In Slovak.)

5. Szeghy P, Popper M. Analysis of the situation in Slovakia. In: Health and the Roma community, analysis of the situation in Europe. Bulgaria, Czech Republic, Greece, Portugal, Romania, Slovakia, Spain. Madrid: FSG; 2009. p. 153-63.

6. Karam GH, Martin DH, Flotte TR, Bonnarens FO, Joseph JR, Mroczkowski TF, et al. Asymptomatic Chlamydia trachomatis infections among sexually active men. J Infect Dis. 1986 Nov;154(5):900-3.

7. Zimmerman HL, Potterat JJ, Dukes RL, Muth JB, Zimmerman HP, Fogle JS, et al. Epidemiologic differences between chlamydia and gonorrhea. Am J Public Health. 1990 Nov;80(11):1338-42.

8. Jarcuska P, Bobakova D, Uhrin J, Bobak L, Babinska I, Kolarcik P, et al.; HEPA-META team. Are barriers in accessing health services in the Roma population associated with worse health status among Roma? Int J Public Health. 2013 Jun;58(3):427-34.

9. Madarasová Gecková A, Jarčuška P, Mareková M, Pella D, Siegfried L, Jarčuška P, et al.; HepaMeta Team. HepaMeta - Prevalence of hepatitis $\mathrm{B} / \mathrm{C}$ and metabolic syndrome in population living in separated and segregated Roma settlements: a methodology for a cross-sectional populationbased study using community-based approach. Cent Eur J Public Health. 2014 Mar;22 Suppl:S6-11.

10. Kabakchieva E, Amirkhanian YA, Kelly JA, McAuliffe TL, Vassileva S. High levels of sexual HIV/STD risk behaviour among Roma (Gypsy) men in Bulgaria: patterns and predictors of risk in a representative community sample. Int J STD AIDS. 2002 Mar;13(3):184-91.

11. Kabakchieva E, Vassileva S, Kelly JA, Amirkhanian YA, DiFranceisco WJ, McAuliffe TL, et al. HIV risk behavior patterns, predictors, and sexually transmitted disease prevalence in the social networks of young Roma (Gypsy) men in Sofia, Bulgaria. Sex Transm Dis. 2006 Aug;33(8):485-90.

12. Kelly JA, Amirkhanian YA, Kabakchieva E, Vassileva S, McAuliffe TL, DiFranceisco, WJ, et al. Prevention of HIV and sexually transmitted diseases in high risk social networks of young Roma (Gypsy) men in Bulgaria: randomised controlled trial. BMJ. 2006 Nov 25;333:1098-1101.

13. Hiršl-Hećej V, Šikanić-Dugić N, Pavelić-Trudić T, Kani D. Prevalence of chlamydial genital infection in adolescent girls and association with risk factors. Int J STD AIDS. 2001;12 Suppl 2:109-10.

14. Shafer MA, Moncada J, Boyer CB, Betsinger K, Flinn SD, Schachter J. Comparing first-void urine specimens, self-collected vaginal swabs, and endocervical specimens to detect Chlamydia trachomatis and Neisseria gonorrhoeae by a nucleic acid amplification test. J Clin Microbiol. 2003 Sep;41(9):4395-9.

15. Stamm WE. Chlamydia trachomatis infections: progress and problems. J Infect Dis. 1999 Mar;179 Suppl 2:S380-3.

16. Miller WC, Hoffman IF, Owen-O'Dowd J, McPherson JT, Privette A, Schmitz JL, et al. Selective screening for chlamydial infection: which criteria to use? Am J Prev Med. 2000 Feb;18(2):115-22.

17. Ginocchio RH, Veenstra DL, Connell FA, Marrazzo JM. The clinical and economic consequences of screening young men for genital chlamydial infection. Sex Transm Dis. 2003 Feb;30(2):99-106.

18. Domeika M, Hallén A, Karabanov L, Chudomirova K, Gruber F, Unzeitig $\mathrm{V}$, et al. Chlamydia trachomatis infections in eastern Europe: legal aspects, epidemiology, diagnosis, and treatment. Sex Transm Infect. 2002 Apr;78(2):115-9.

19. Kučinskienė V, Šutaitė I, Valiukevičienė S, Milašauskienė Ž, Domeika M Prevalence and risk factors of genital Chlamydia trachomatis infection. Medicina (Kaunas). 2006;42(11):885-94.

20. Kacena KA, Dohnal K, Benesova V, Grivna M, Deliopolu J, Trýzna R, et al. Chlamydia, gonorrhea, and HIV-1 prevalence among five populations of women in the Czech and Slovak Republics. Sex Transm Dis. 2001 Jun;28(6):356-62.

21. Jarčuška P, Liptáková A. Epidemiology of C. trachomatis in Slovakia. In: International Conference on Chlamydial Infection: abstract collection; 2003 Nov 13-15; Brno, Czech Republic.

22. Šimko J, Jarčuška P. Chlamydial infections of the genitourinary tract clinical manifestations, diagnosis and treatment. Bratislava: Pliva; 2004. (In Slovak.)

23. Balogová L. Chlamydia trachomatis - a cause of infertility in women [dissertation]. Košice: Pavol Jozef Šafárik University in Košice; 2007. (In Slovak.) 
24. Špiláková N, Balogová L, Jarčuška P, Liptáková A, Vološinová D, Šimko J. Screening of Chlamydia trachomatis in the Slovak Republic. In: IX Slovak - Czech Congress on Infectious Diseases: abstracts; 2005 Jun 9-11; Košice, Slovak Republic. Košice; 2005. p. 65. (In Slovak.)

25. Jarčuška P, Liptáková A, Mantičová I, Repčáková M, Balogová L, Špiláková N, et al. Screening of Chlamydia trachomatis induced infections in female university population. Lek Obz. 2005;54(2):48-51. (In Slovak.)
26. Točková J, Čisláková L. Chlamydia trachomatis and genitourinary infections - classification, epidemiology and incidence. Slov Lek. 2006;16:879. (In Slovak.)

27. Balogová L, Jarčuška P, Pilátová M, Vološinová D. Infection of Chlamydia trachomatis in chosen group of population. Intern Med. 2009;9:19.

28. Vološinová D, Jarčuška P. Incidence of C. trachomatis in Slovak professional soldiers. Acta Chemotherap. 2010;19-20(3):124-8. (In Slovak.) 